\title{
Effect of Reducing Sugar and Total Nitrogen to Ethanol Production from Molasses by Saccharomyces cerevisiae
}

\author{
Ekwan Nofa Wiratno $^{1 *}$, Tri Ardyati $^{1}$, Agustin Krisna Wardani ${ }^{2}$ \\ ${ }^{1}$ Department of Biology, Faculty of Mathematics and Natural Sciences, University of Brawijaya, Malang, Indonesia \\ ${ }^{2}$ Department of Agricultural Product Technology, Faculty of Agriculture Technology, University of Brawijaya, Malang, \\ Indonesia
}

\begin{abstract}
Indonesia's oil production has declined, while demand for derivative products is increasing. Objective of this research are to understand effect of reducing sugar and total nitrogen variation to ethanol production and fermentation efficiency, cell viability, acidity, temperature, dissolved oxygen with molasses by Saccharomyces cerevisiae (SAF Instant). Step of this research consist of determination of reducing sugar, ethanol fermentation, total nitrogen determination, ethanol determination and data analysis. Treatment of reducing sugar (GR) and total nitrogen (N) (g. $\mathrm{L}^{-1}$ ) that are GR 100 N 0, GR 100 N 6, GR 100 N 10, GR 125 N 0, GR 125 N 6 and GR 125 N 10. Fermentation was carried out for 72 hours with three replications. Observation parameters every 24 hours are ethanol and reducing sugar concentration, temperature, acidity and dissolved oxygen. Highest ethanol resulted from GR $125 \mathrm{~N} 6\left(3.68 \mathrm{~g} . \mathrm{L}^{-1}\right)$ and GR $100 \mathrm{~N} 6\left(3.53 \mathrm{~g} . \mathrm{L}^{-1}\right)$. Low reducing sugar consumption inhibited by by-product of yeast metabolism and molasses chemical compound, lead leaves high sugar concentration (> 80 g. $\mathrm{L}^{-1}$ ). GR $100 \mathrm{~N} 6$ and GR $125 \mathrm{~N} 6$ have highest fermentation efficiency ( 69 and 57 $\%)$. There was no increase in temperature and decrease in $\mathrm{pH}$ significantly $(\alpha>0.05)$. Dissolved oxygen decreased significantly $(\alpha>0.05)$ at the early of fermentation and decrease until the end of fermentation. Total nitrogen $6 \mathrm{~g}$ g. $\mathrm{L}^{-1}$ has the highest fermentation efficiency.
\end{abstract}

Keywords: ethanol, molasses, reducing sugar, Saccharomyces cerevisiae, total nitrogen

\section{INTRODUCTION}

Indonesia's oil production has declined, while demand for derivative products is increasing. Comparison of ethanol and the need for production in 2012 reached 15: 1 [1]. One of the solutions is use ethanol for replacing fossil fuel. The advantages of ethanol use for transportation purpose that it can be produced every time and low of $\mathrm{CO}^{2}$ emission [2].

Saccharomyces cerevisiae is active microbe in the conversion of glucose to ethanol. Yeast growth is influenced by nutritional factors and environmental factors. The main nutrients that are important in the life of yeast cells are source of carbon, nitrogen, oxygen, and hydrogen. Other materials needed in small amounts for the cell (element phosphorus, sulphur, potassium and magnesium). The critical environmental parameters are temperature, $\mathrm{pH}$, and oxygen and air pressure [3].

The major raw material for ethanol production in Indonesia is molasses. Molasses is a sugar cane factory waste and is not widely used as a staple food as in the case with starchy

\footnotetext{
* Correspondence author:

Ekwan Nofa Wiratno

Email : ekwannwiratno@gmail.com

Address : Faculty of Mathemathics and Natural Sciences, University of Brawijaya, Jl. Veteran, Malang, 65145
}

materials [4]. Molasses has been used because this material does not require pre-treatment processes, so microbes can use it directly for metabolism [5].

However, the use of the concentration of reducing sugar in the molasses as a carbon source and additional nutrients in the form of urea as a nitrogen source was varied in each industry that use it. This research is important to understand the variation on the use of reducing sugars and total nitrogen in increasing ethanol production which is expected to encourage energy independence and reduce reliance on fossil energy sources.

\section{MATERIALS AND METHODS \\ Total Nitrogen and Calcium (Ca) Concentration Measurement}

Total nitrogen measured use the Kjeldahl method [6]. Calcium concentration of molasses use Indonesian standard method/SNI [6].

\section{Measurement of Reducing Sugar Concentration \\ Concentrations of reducing sugar of pure molasses and molasses was measured for every 24 hours in the fermentation process using 3,5- dinitrosalicylic (DNS) method [7].}




\section{Ethanol Fermentation}

The molasses was diluted with distilled water to make a reducing sugar concentration $125 \mathrm{~g} . \mathrm{L}^{-1}$ and urea has added $0.37 \mathrm{~g} . \mathrm{L}^{-1}(\mathrm{pH} 5.5)$. Molasses was boiled at a temperature of $100^{\circ} \mathrm{C}$ for 10 minutes. The fermentation processes was consist of enrichment, pre-fermentation and fermenta tion.

Total of $20 \mathrm{ml}$ of sterile molasses was added with $2 \mathrm{~g}$ of SAF Instant Yeast Gold Label and homogenized at a speed of $120 \mathrm{rpm}$ for 3 hours at $30^{\circ} \mathrm{C}$ (enrichment). These results was poured into a sterile molasses to the volume of $200 \mathrm{ml}$ and incubated at a speed of $120 \mathrm{rpm}$ for 12 hours at $30^{\circ} \mathrm{C}$ (pre-fermentation). After it was moved to the sterile molasses with reducing sugar concentration and nitrogen setting (Table 1) to $1000 \mathrm{ml}$ volume and incubated at a speed of 300 rpm for 72 hours.

Table 1. Treatment of Total $\mathrm{N}$ and reducing sugar concentration

\begin{tabular}{ccc}
\multicolumn{3}{c}{ Concentration } \\
\multirow{2}{*}{ No } & \multicolumn{2}{c}{ Treatment } \\
\cline { 2 - 3 } & Reducing Sugar $\left(\mathbf{g} \cdot \mathbf{L}^{-1}\right)$ & Total Nitrogen $\left(\mathbf{g} \cdot \mathbf{L}^{-1}\right.$ ) \\
\hline 1 & 100 & 2.7 \\
2 & 100 & 6 \\
3 & 100 & 10 \\
4 & 125 & 3.3 \\
5 & 125 & 6 \\
6 & 125 & 10 \\
\hline
\end{tabular}

\section{Ethanol Measurement}

Ethanol concentration was measured using Dichromatic Acid Method [8].

\section{Fermentation Efficiency}

Fermentation efficiency was estimated using theoretical and real concentration of ethanol [9].

$$
\begin{aligned}
& \mathrm{TE}=\mathrm{SK} \times \mathrm{V} \times 0.511 \\
& \mathrm{FE}=\frac{\text { Ethanol total } \text {-Initial ethanol }}{\text { End sugar }- \text { Initial sugar }} \\
& \mathrm{FE}=\frac{\text { Ethanol Yield (g) }}{\text { Theoretical ethanol }} \times 100 \% \\
& \begin{aligned}
\text { Description: } \\
\text { TE } \quad=\text { theoretical ethanol } \\
\text { SK } \quad=\text { sugar concentration } \\
\text { V } \quad=\text { volume of fermentation medium } \\
\text { FE } \quad=\text { fermentation efficiency }
\end{aligned}
\end{aligned}
$$

\section{Fermentation Parameter}

Parameters was measured consisted of acidity, temperature and dissolved oxygen (DO). Acidity was measured using $\mathrm{pH}$ meter, the temperature measured by the thermometer, while DO was measured with DO meter.

\section{RESULT AND DISCUSSION}

\section{Ethanol Production and Reducing Sugar Concentration}

Highest ethanol concentration was produced is GR $100 \mathrm{~N} 6$ (35.3 g. $\mathrm{L}^{-1}$ or $3.53 \%$ ) (Fig. 1) and GR $125 \mathrm{~N} 6$ (36.85 g. $\mathrm{L}^{-1}$ or 3.68 \%) (Fig. 2). Increasing of ethanol concentrations was significantly $(\alpha>$ 0.05 ) occurred at 24 hours. Largest ethanol production occurs in the first 24 hours in the fermentation process [10]. This is caused by an increase in the fermentation process up to $10 \%$ in the early phase of fermentation [11].

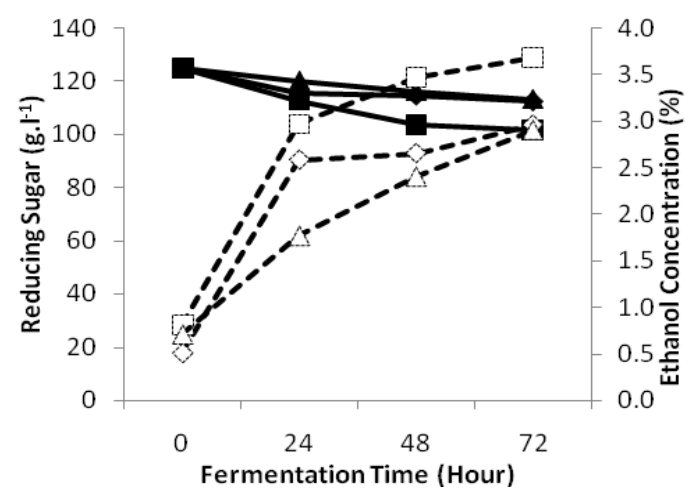

Figure 1. Effect of reducing sugar initial concentration 125 g. $\mathrm{L}^{-1}$ to reducing sugar concentration (close symbol) and ethanol concentration (open symbol)

Total nitrogen $\left.0.27 \& 0.33 \mathrm{~g} . \mathrm{L}^{-1}(\diamond \diamond)\right), 6 \mathrm{~g} . \mathrm{L}^{-1}($ \& $\mathrm{D}), 10 \mathrm{~g} . \mathrm{L}^{-1}(\mathbf{\Delta} \& \Delta)$

Result of ethanol fermentation with treatment of GR $100 \mathrm{~N} 6$ and GR $125 \mathrm{~N} 6$ were significantly differences with the other $(\alpha=0.05)$. Reducing sugar concentration of $125 \mathrm{~g} . \mathrm{L}^{-1}$ resulted in higher ethanol concentrations than reducing sugar $100 \mathrm{~g} . \mathrm{L}^{-1}$. Ethanol yield is influenced by the concentration of the substrate, the higher the substrate (not more than $15 \%$ ), produced the higher ethanol yield [12].

Treatment of total nitrogen $6 \mathrm{~g} . \mathrm{L}^{-1}$ influence the concentration of produced ethanol. Addition of urea for increasing nitrogen concentration which produced the maximum ethanol concentration was $6 \mathrm{~g} . \mathrm{L}^{-1}$. Nitrogen is a major nutrient that influence fermentation efficiency and at the same time also become a limiting factor to the fermentation process. Limitations of the nitrogen will lead to a decrease in sugar transport activity in the stationary phase resulting in a decrease in the rate of 
fermentation. The presence of nitrogen triggers the rate of metabolism of sugar and ethanol production [13].

Reducing sugar in all treatments decreased slightly so that a reducing sugar is still remains in a high concentration. This indicates that the fermentation process is not running optimally. Inhibition of this process of reducing sugar consumption may occur due to the influence of chemical compounds inside the compound of molasses and yeast cell metabolism. One of the compounds derived from molasses is sulphur dioxide [14].

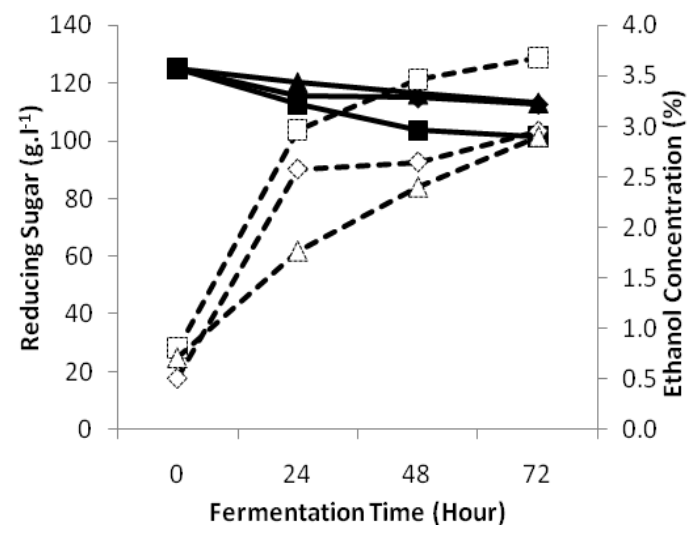

Figure 2. Effect of reducing sugar initial concentration 100 g. $\mathrm{L}^{-1}$ to reducing sugar concentration (close symbol) and ethanol concentration (open symbol)

Total nitrogen $0.27 \& 0.33 \mathrm{~g} . \mathrm{L}^{-1}(\diamond \& \diamond), 6 \mathrm{~g} . \mathrm{L}^{-1}(\square$ \& $\square), 10 \mathrm{~g} \cdot \mathrm{L}^{-1}(\mathbf{\Delta} \& \Delta)$

Sulphur dioxides have antimicrobial effects by means of penetrating cell membranes and interfere with the activity of enzymes and proteins in the cell. When sulphur dioxide is added to the fermentation process, there will be a decrease in the rate of fermentation and increased production of acetaldehyde. Sulphur dioxide inhibits an enzyme that inhibits the $\mathrm{SH}$ group and NAD [15].

Some of the yield compounds of yeast cell metabolism include furfural, 5-hydroxymethylfurfural (HMF), acetic acid [15] and propionic acid [16]. Furfural and HMF at concentrations more than $0.5 \%$ led to a decrease in sugar consumption and a decrease in the concentration of ethanol (7.5\% and $26 \%)$. While the acetic acid concentration more than $0.15 \%$ causes reduction of ethanol concentration and productivity [17]. Furfural was caused to the accumulation of reactive oxygen species (ROS), mitochondrial membrane damage, and damage to the vacuole membrane, nucleus and actins chromatin damage [18]. Concentration of $0.68 \%$ propionic acid is toxic for Saccharomyces cerevisiae [17].

\section{Effect of Reducing Sugar and Total Nitrogen to Fermentation Efficiency}

The highest fermentation efficiency is GR 100 N 6 treatment (69\%). This was followed by treatment of the GR $125 \times 6$ by $57 \%$. This fermentation efficiency showed that the total nitrogen treatment at $6 \mathrm{~g} . \mathrm{L}^{-1}$ was able to improve the efficiency of fermentation. Fermentation media in the form of molasses had a fermentation efficiency of $68.5 \%$ [11]. The decline in the efficiency of the fermentation was due to the high concentration of reducing sugars and other components that were toxic [19].

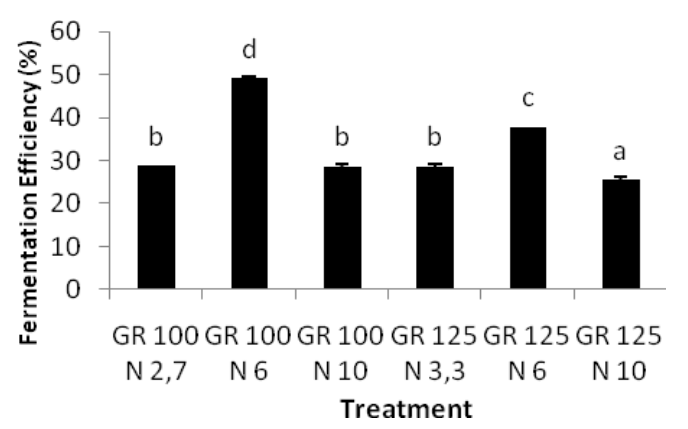

Figure 3. Ethanol Fermentation Efficiency after 72 hour

Efficiency of ethanol fermentation decreases with increase in sugar concentration resulting in increased osmotic pressure of the media or the number of cells that over capacity due to the high concentration of substrate. The high concentration of substrate inhibits the growth of yeast cells that lead to high osmotic pressure and low water concentration. This causes the yeast cells become dehydrated [20]. $\mathrm{N}$ concentration of $6 \mathrm{~g} . \mathrm{L}^{-1}$ led to the increased cell viability so that the process of carbohydrate metabolism (ethanol fermentation) increased [21].

\section{Effect of Reducing Sugar and Total Nitrogen to Fermentation Parameters ( $T$, pH and DO)}

An increase on temperature of all treatments during the initial fermentation process ( 24 hours) were not significant $(\alpha>0.05)$ (Fig. 4). It indicates the process of carbohydrate metabolism. The increase on temperature in the initial phase of fermentation (first 24 hours) caused by exothermic metabolic activity (heat generating) by the microbial population [11].

Fermentation temperature at initial phase occurred at yeast fermentation of glucose $(9 \mathrm{~g}$ or 
$1.7 \mathrm{kcal})$. The energy is sufficient to raise the temperature of $17.9^{\circ} \mathrm{C}$ medium. Increased of the $17.9^{\circ} \mathrm{C}$ temperature was not observed either because there is a process made possible release into the environment temperature [12].

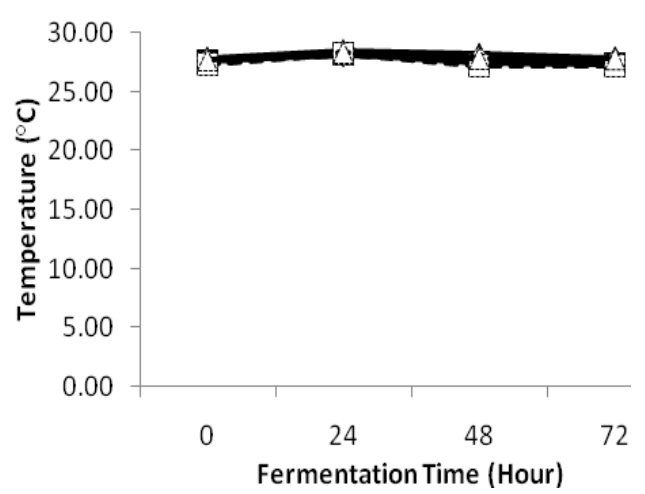

Figure 4. Effect of treatment to temperature during ethanol fermentation

GR $100 \mathrm{~N} 0.27(\diamond), \mathrm{GR} 125 \mathrm{~N} 0.33(0), \mathrm{GR} 100 \mathrm{~N}$ 6 (घ), GR 125 N 6 (), GR 100 N 10 ( $\mathbf{\Delta})$ ), GR 125 $\mathrm{N} 10(\Delta)$

In general, a decrease of the acidity $(\mathrm{pH})$ in all treatments of the fermentation process, were not significant $(\alpha>0.05)$ (Fig. 5). According to Khongsay et al. [22], when the fermentation process using a batch system, decrease the acidity of the medium to 0.25 in the early phase of fermentation (24 hours), then a decrease in $\mathrm{pH}$ occurs slowly.

When the yeast to metabolize carbohydrates also produced acetic acid and formic acid, has cause decrease of the acidity of the growth medium. Decrease of the acidity is closely linked to the consumption of nitrogen and release of $\mathrm{H}^{+}$ ions. The acid is lipo-soluble can enter the cell through the plasma membrane and intracellular acidity affect [23].

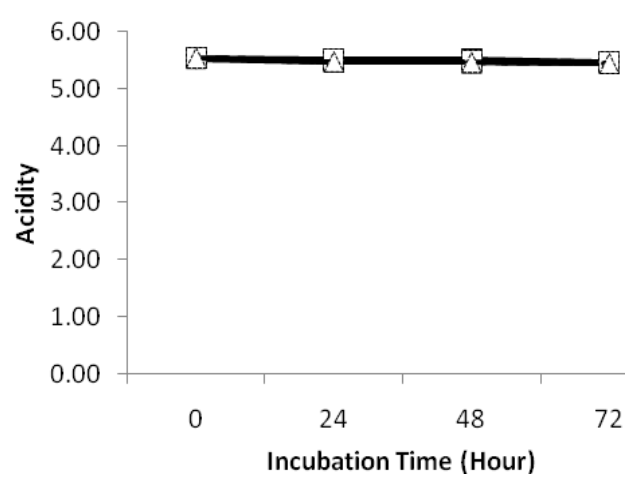

Figure 5. Effect of treatment to acidity during ethanol fermentation

GR $100 \mathrm{~N} 0.27(\bullet)$, GR $125 \mathrm{~N} 0.33(0), \mathrm{QR} 100 \mathrm{~N}$

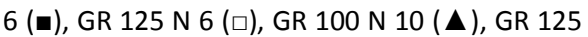
$\mathrm{N} 10(\Delta)$
Increasing the concentration of acetic acid causes a decrease in carbohydrate consumption. It is resulting in a decrease in the rate of ethanol production [24].

There was a decrease of dissolved oxygen during the process of fermentation in all treatments (Fig. 6). Decrease of the DO was significantly ( $\alpha>0.05)$ occurred in the treatment of GR 100 N 6, GR 100 and GR 125 N 10 N 10 This indicated that the concentration of total nitrogen

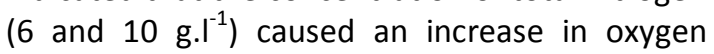
consumption by yeast cells.

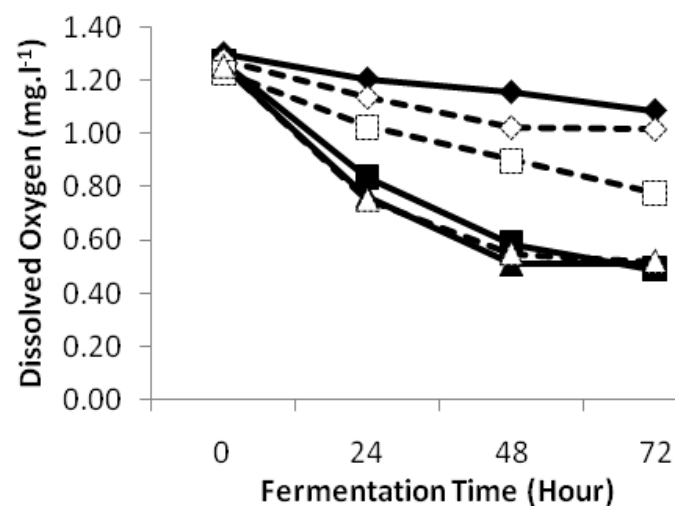

Figure 6. Effect of treatment to dissolved oxygen during ethanol fermentation

GR 100 N 0.27 (४), GR 125 N $0.33($ (४), GR 100 N 6 (घ), GR 125 N 6 (), GR 100 N 10 ( $\Delta$ ), GR 125 $\mathrm{N} 10(\Delta)$

Yeasts used oxygen in the process of cell reproduction that would correlate with the number of cells [25] and keep the cell concentration remains high [26]. The presence of oxygen will inhibit the fermentation process (Pasteur Effect) [25]. The function of oxygen is to produce ATP in glycolysis and oxidative phosphorylation. The process of oxidative phosphorylation is a process that is most prominent in the production of ATP. If there is no oxygen (anaerobic), NADH in the mitochondria cannot be re-oxidized in the citric acid cycle, resulting in the formation of ATP and nutrient solution is interrupted [21]. In addition of nitrogen, other factors that affect the process of respiration are the presence of salt. The addition of $1.0 \mathrm{M} \mathrm{KCl}$ or $\mathrm{NaCl}$ causes an increase in the rate of respiration and cell metabolism [27].

\section{CONCLUSION}

Highest ethanol concentration resulted GR 125 N 6 (3.68 g.L-1) and GR 100 N 6 (3.53 g.L-1) treatment. Low reducing sugar consumption inhibited by by-product yeast metabolism and 
molasses chemical compound, lead remains high sugar concentration (> 80 g.L-1). GR 100 N 6 and GR 125 N 6 treatment have highest fermentation efficiency (69 and 57\%). There was no increase in temperature and decrease in $\mathrm{pH}$ significantly $(\alpha>0.05)$. DO decreased significantly $(\alpha>0.05)$ at the early of fermentation and slowed until the end of fermentation. Total nitrogen 6 g.L-1 had the highest fermentation efficiency.

\section{REFERENCES}

[1] ESDM. 2012. Produksi, konsumsi, ekspor dan impor minyak Indonesia 2009. http://www.migas.esdm.go.id/wap/?op=Be rita\&id=2787. Accessed June $26^{\text {th }} 2012$.

[2] Jeon, Y., S.J. Kim, D.H. Kim, B.K. Na, D.H. Park, H.T. Tran, R. Zhang, D.H. Ahn. 2007. Development of a serial bioreactor system for direct etanol production from starch using Aspergillus niger and Saccharomyces cerevisiae. Biotechnol. Bioprocess Eng. 12. 566-573.

[3] Loureiro, V., M. Malfeito-Ferreira. 2003. Spoilage yeasts in the wine industry. Int. J. Food Microbiol. 86 (1-2). 23-50.

[4] Kurniawan, Y., A. Susmiadi, A. Toharisman. 2005. Potensi pengembangan industri gula sebagai penghasil energi di Indonesia. Research Centre of Sugar Plantation Indonesia (P3GI). Pasuruan.

[5] da Silva, G.P., E.F. de Araújo, D.O. Silva, W.V. Guimarães. 2005. Ethanolic fermentation of Sucrose, Sugarcane Juice and Molasses by Escherichia coli Strain Ko11 and Klebsiella oxytoca Strain P2. Braz. J. Microbiol. 36. 395-404.

[6] Sudarmadji, S., Haryono, B. Suhardi. 1996. Analisa bahan makanan dan pertanian. Liberty. Yogyakarta.

[7] Miller, G.L.. 1959. Use of Dinitrosalicylic Acid Reagent for Determination of Reducing Sugar. Analytical Chemistry 3 (31): 426-248.

[8] Caputi, A. Jr, M. Ueda, T. Brown. 1968. Spectrophotometric determination of ethanol in wine. Am. J. Enol. Viticult. 3 (19). 160-165.

[9] Zhang, K., H. Feng. 2010. Fermentation potentials of Zymomonas mobilis and its application in ethanol production from lowcost raw sweet potato. Afr. J. Biotechnol. 9 (37). 6122-6128

[10] Balakumar, S., V. Arasaratnam. 2009. Comparison of industrial scale ethanol production from palmyrah-based carbon source by commercial yeast and a mixed culture from palmyrah toddy. J. Instr. Brewer. 115 (2). 105-109.

[11] Ingledew, M.W. 1993. Yeasts for production of fuel ethanol. The Yeasts. 5. 245-286.

[12] Rodrigues, F., P. Ludovico, C. Leao. 2005. Sugar metabolism in yeasts: an overview of aerobic and anaerobic glucose catabolism. University of Minho. Braga.

[13] Ghosh, S., R. Chakraborty, U. Raychaudhuri. 2010. Modulation of palm wine fermentation by the control of carbon and nitrogen source on metabolism of Saccharomyces cerevisiae. J. Food Technol. 8 (5). 204-210.

[14] Foster, F. 2012. Harmful chemicals in Molasses. http://www.rawfoodexplained. com/junk-foods-molasses/harmful-chemi cals-in-molasses.html. Accessed October $3^{\text {rd }}$ 2012.

[15] Henderson, P.. 2009. Sulfur Dioxide, science behind this anti-microbia, anti-oxidant, wine additive. Pract. Winery Vineyart J. 1-6.

[16] Al-Jasass, F.M., S.M. Al-Eid, S.H.H. Ali. 2010. A comparative study on date syrup (dips) as substrate for the production of baker's yeast (Saccharomyces cerevisiae). J. Food, Agr. Environ. 8 (2). 314-316.

[17] Wikandari, R., R. Millati, S. Syamsiyah, R. Muriana, Y. Ayuningsih. 2010. Effect of Furtural, Hydroxymethylfurfural and Acetic Acid on indigeneous Microbial Isolate for Bioethanol production. Agr. J. 5 (2). 105109.

[18] Allen, S.A., W. Clark, J. M. McCaffery, Z. Cai1, A. Lanctot1, P.J. Slininger, Z.L. Liu, S.W. Gorsich. 2010. Furfural induces reactive oxygen species accumulation and cellular damage in Saccharomyces cerevisiae. Biotechnol. Biofuels. 3. 2-10.

[19] Abubaker, H.O., A.M.E. Sulieman, H.B. Elamin. 2012. Utilization of Schizosaccharomyces pombe for Production of ethanol from Cane Molasses. J. Microbiol. Res. 2 (2). 36-40.

[20] Soni, S.K., N. Bansali, R. Soni. 2009. Standardization of conditions for fermentation and maturation of wine from Amla (Emblica officinalis Gaertn.). Nat. Product Radiance. 8 (4). 436-444.

[21] Supriyanto, T., Wahyudi. 2010. Proses produksi etanol oleh Saccharomyces cerivisiae dengan Operasi kontinyu pada kondisi vakum. University of Diponegoro. Semarang. 
[22] Khongsay, N., L. Laopaiboon, P. Jaisil, P. Laopaiboon. 2012. Optimization of agitation and aeration for very high gravity ethanol fermentation from sweet sorghum juice by Saccharomyces cerevisiae using an orthogonal array design. Energ. 5. 561-576.

[23] Maurice, M.L. 2011. Factors effecting ethanol fermentation via simultaneous saccharification and fermentation. Shanghai Jiao Tong University. Shanghai.

[24] Casey, E., M. Sedlak, N.W.Y. Ho, N. S. Mosier. 2010. Effect of acetic acid and $\mathrm{pH}$ on the cofermentation of glucose and xylose to ethanol by a genetically engineered strain of Saccharomyces cerevisiae. FEMS Yeast Res. 10. 385-393.

[25] Walker, G.M. 1998. Yeast: physiology and biotechnology. John Wiley and Sons. Chichester.

[26] Tao, F., J.Y. Miao, G.Y. Shi, K.C. Zhang. 2003. Etanol fermentation by an Acid-tolerant Zymomonas mobilis under non-sterilized condition. Process Biochem. 40. 183-187.

[27] Montiel, V., J. Ramos. 2007. Intracellular $\mathrm{Na}^{+}$ and $\mathrm{K}^{+}$distribution in Debaryomyces hansenii. Cloning and expression in Saccharomyces cerevisiae of DhNHX1. FEMS Yeast Res. 7. 102-109. 